\title{
THE MID-BRUNHES EVENT IN THE SOUTHWESTERN ATLANTIC OCEAN: COCCOLITHOPHORE ASSEMBLAGES DURING THE MIS 11-9
}

\author{
ADRIANA LEONHARDT \\ Instituto de Oceanografia, Universidade Federal do Rio Grande, Av. Itália, km 8, Cx.P. 474, 96201-900, Rio Grande, Brasil. \\ adriana.leonhardt@yahoo.com.br \\ FELIPE A.L. TOLEDO \\ Instituto Oceanográfico, Universidade de São Paulo, Praça do Oceanográfico, 191, 05508-900, São Paulo, Brasil. \\ ftoledo@usp.br \\ JOÃO CARLOS COIMBRA \\ Instituto de Geociências, Universidade Federal do Rio Grande do Sul, Av. Bento Gonçalves, 9500, Cx.P. 15001, \\ 91501-970, Porto Alegre, Brasil.joao.coimbra@ufrgs.br
}

\begin{abstract}
The paleoceanographic dynamics in the Southwestern Atlantic Ocean is still poorly understood, with most studies describing the last $25 \mathrm{ky}$. In the present study, the coccolithophore assemblages from a sediment core from the Brazilian continental margin ( $20^{\circ} 01^{\prime} \mathrm{S}$ ) were analysed during the interval between 423-305 ky (Marine Isotopic Stages - MIS - 11 to 9), including the important Mid-Brunhes Event (MBE). The coccolithophore assemblage is typically tropical: Gephyrocapsa spp. and Florisphaera profunda dominate the assemblage. The productivity (measured by the $N$ ratio) was high throughout the entire studied interval, pointing to a shallow nutricline, induced by the northeast winds of the South Atlantic Subtropical High or by upwelling development. The coccolith numbers was low during almost all the studied interval, since this group is adapted to oligotrophic environments. However, between 420-410 ky, both coccolith numbers and $N$ ratio were high, which may indicate the lack of silicate in the surface waters (reducing the diatom competitiveness). Globally, the MBE is marked by a high production of carbonate and the dominance of Gephyrocapsa caribbeanica in the coccolithophore assemblages. In this work, this dominance was recognized between 420-328 ky (MIS 11-9). Besides the high production of carbonate, the MBE is also globally marked by a great dissolution (Mid-Brunhes Dissolution Interval), but no significant carbonate dissolution was found in this work.
\end{abstract}

Key words: Mid-Brunhes Event, Mid-Brunhes Dissolution Interval, coccolithophorids, productivity, Southwestern Atlantic.

RESUMO - A dinâmica paleoceanográfica no Oceano Atlântico Sudoeste ainda é pobremente compreendida, com a maioria dos estudos descrevendo os últimos $25 \mathrm{ky}$. Neste trabalho, as assembleias de cocolitoforídeos de um testemunho sedimentar da Margem Continental Brasileira (2001'S) foram analisadas durante o intervalo entre 423-305 ky (Estágios Isotópicos Marinhos - EIM - 11 a 9), incluindo o importante Evento do Brunhes Médio. A assembleia de cocolitoforídeos é tipicamente tropical: Gephyrocapsa spp. e Florisphaera profunda dominam a assembleia. A produtividade (medida pela razão $N$ ) foi alta durante todo o intervalo estudado, apontando para uma nutriclina rasa, induzida pelos ventos de nordeste da Alta Subtropical do Atlântico Sul ou pelo desenvolvimento de ressurgência. A abundância de cocólitos foi baixa durante quase todo intervalo estudado, já que este grupo é adaptado a condições oligotróficas. De qualquer forma, entre 420-410 ky, tanto a abundância de cocólitos quanto a razão $N$ foram altas, o que pode indicar escassez de silicato nas águas superficiais (reduzindo a competitividade das diatomáceas). Globalmente, o Evento do Brunhes Médio é marcado por alta produção de carbonato e a dominância de Gephyrocapsa caribbeanica nas assembleias de cocolitoforídeos. Neste trabalho, esta dominância foi reconhecida entre 420-328 ky (EIM 11-9). Apesar da alta produção de carbonato, o Evento do Brunhes Médio também é globalmente marcado por uma grande dissolução (Intervalo de Dissolução do Brunhes Médio), mas uma dissolução de carbonato significativa não foi registrada neste trabalho.

Palavras-chave: Evento do Brunhes Médio, Intervalo de Dissolução do Brunhes Médio, cocolitoforídeos, produtividade, Atlântico Sudoeste. 


\section{INTRODUCTION}

Periods marked by intense climate change are subject of great scientific interest because they contain the keys to understanding the climate system as a whole. One of these intervals is the Mid-Brunhes Event (MBE), centered on the Marine Isotopic Stage (MIS) 11, when oceanographic changes not fully understood took place.

Jansen et al. (1986) investigated widely spread cores trying to understand the MBE: according to the authors, in the Southern Hemisphere the climate signal shows a transition to "interglacial-like" conditions, related to an intensified atmospheric and oceanic circulations, which could lead to a shallower nutricline and enhanced productivity in this interval. In the Northern Hemisphere, the conditions become more "glacial" during the MBE, with a zonal circulation.

Data from ice cores in Antarctica show that the period between 740-430 kyr (pre-MBE) was characterized by less pronounced warmth in interglacial periods, but a higher proportion of each cycle was spent in the warm mode, in comparison with the four most recent glacial cycles (EPICA, 2004). The MBE marks the onset of the late Quaternary regime of glacial cycles with enhanced glacial/interglacial contrast. In a general way, it can be said that before the MBE, interglacial periods seem to be characterized by larger continental ice sheets, lower sea level, cooler temperatures in Antarctica and lower atmospheric $\mathrm{CO}_{2}$ concentrations. After the MBE, simulations suggest that later interglacials are warmer primarily because of increased global mean temperatures during Northern Hemisphere winters. This warmth arises from increased insolation during this season in conjunction with increased atmospheric greenhouse-gas concentrations, leading to feedbacks between sea ice, temperature, evaporation and salinity (Yin \& Berger, 2010; Yin, 2013).

Proxy evidence for the continental climate in Britain gives us a different panorama: the pre-MBE interglacials were as warm as post-MBE interglacials. This is consistent with the surface sea temperature in the North Atlantic region, but is in strong contrast with temperature records from Antarctica and the Southern Ocean (Candy et al., 2010). Even considering only the Northern Hemisphere, there are discrepancies about the geographic scope of the MBE. There is no evidence for an MBE in the mid-latitude North Atlantic $\left(40-56^{\circ} \mathrm{N}\right)$, but north of $56^{\circ} \mathrm{N}$ and in the Nordic Seas there is evidence for lower temperatures during MIS 19-13 in relation to MIS 11-1, showing a strong spatial difference in temperature conditions (Candy \& McClymont, 2013). The true geographical extent of the MBE is currently unclear. For the Southwestern Atlantic, there is even less data available for comparisons.

The MBE is centered on the MIS 11 (428-397 kyr), which is an exceptionally long interglacial warm period. It is important to say that MIS 11 seems to be a better analogue for the present interglacial than MIS 5e. The insolation over MIS 11 shows a strong linear correlation with the insolation signal over the recent past and the future (far less than the amplitude at MIS 5), particularly MIS 11c (Loutre \& Berger, 2000; Tzedakis et al., 2012). Simulations show that both MIS
11 and the future are characterized by small amount (if any) of continental ice, with almost no variation during the whole interval. In contrast, MIS 5 is exhibiting larger variability in simulated ice volume. The comparison between MIS 5 and MIS 11 shows that a long-lasting high $\mathrm{CO}_{2}$ concentration can prevent ice sheets from growing if the amplitude of insolation change is small (as in MIS 11) (Loutre \& Berger, 2003).

In the paleontological aspect, the MBE is marked by the dominance of the coccolithophore Gephyrocapsa caribbeanica. This dominance is global in nature (but its beginning is somehow diachronous, since it probably occurred earlier in the high-latitude North Atlantic) (Bollman et al., 1998). Therefore, the coccolithophore assemblage could help to trace the MBE extent in a particular location.

The interval of the coccolithophore bloom coincides with global carbonate dissolution (Wang et al., 2014), other motive by which this is a very interesting paleoceanographic event. According to Barker et al. (2006), one possible cause of the Mid Brunhes Dissolution Interval (MBDI) is a global increase in pelagic carbonate production that may have been a key driver of such widespread dissolution during the MBDI. However, the atmospheric $\mathrm{CO}_{2}$ was no higher during the MIS 11 than more recent interglacial periods, as would be expected for a period of enhanced production of carbonate ( $\mathrm{CO}_{2}$ paradox of MIS 11) (Barker et al., 2006). The enhanced coccolithophore production may be balanced by the cycle in global ocean carbonate dissolution (increases in carbonate accumulation in some areas of the ocean must be balanced by decreased accumulation elsewhere), which peaks as the globally recognized MBDI (Rickaby et al., 2007). There are very few data on the increased carbonate accumulation during the MBE at the Brazilian continental margin (Ferreira et al., 2014), but the relationship between the enhanced coccolithophore production and the carbonate dissolution has never been explored.

Here, we present coccolith data for the period between 423-300 kyr (MIS 11 to 9, including the MBE), from the Southwestern Atlantic. As the MBE seems to be a global event, high coccolith numbers are expected in the Southwestern Atlantic during this interval, causing the rise of the pelagic carbonate accumulation. Because of that, under the constraints of steady state, we should also find carbonate dissolution. The aims of this work are: (i) investigate the coccolithophore abundance and the paleoproductivity of surface waters during the MBE; (ii) describe the period of dominance of Gephyrocapsa caribbeanica; (iii) observe the MBDI in the Southwestern Atlantic deep waters.

\section{Modern oceanography of the study area}

In the South Atlantic Ocean, the upper-level circulation is dominated by a system of gyres and by the equatorial and circumpolar current systems (Figure 1), controlled by the atmospheric system. The subtropical gyre is associated to a high atmosphere pressure center, the South Atlantic Subtropical High (SASH), which is responsible for the predominance of NE winds in the Brazilian southeast region. The equatorial current system is driven by the trade winds and 


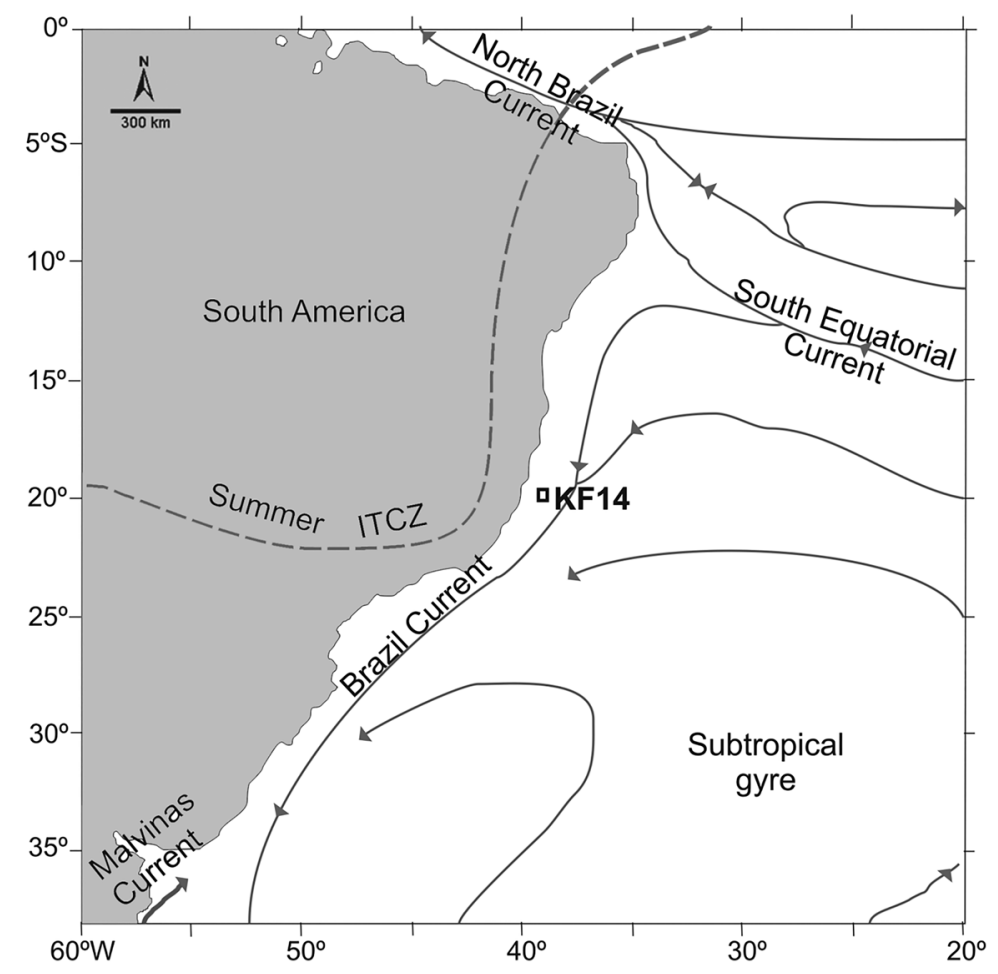

Figure 1. Schematic representation of the large-scale, upper-level circulation in the South Atlantic and the location of KF14 core (modified from Peterson \& Stramma, 1991).

by the Intertropical Convergence Zone (ITCZ). The ITCZ and the SASH migrate throughout the year. During winter in the south hemisphere, the ITCZ reaches its northernmost position (Peterson \& Stramma, 1991) and the SASH, its northwesternmost position (Hastenrath, 1991). Thus, in the studied area, northerly winds prevail in austral summer, while southerly winds dominate in austral winter (Lass \& Mohrholz, 2008).

The studied area is directly influenced by the Brazil Current (BC). It is formed when the South Equatorial Current (SEC) reaches the Brazil shelf region and bifurcates into the North Brazil Current (NBC) and the BC. The local bifurcation is seasonal as well: when the SEC bifurcates in its southernmost position (austral winter), the $\mathrm{NBC}$ transport increases and the $\mathrm{BC}$ transport decreases (Rodrigues et al., 2007).

The sea surface temperature, evaporation, precipitation, and surface current intensity of the $\mathrm{BC}$ are linked to seasonal changes in the wind intensity. The BC flows in open sea, transporting the Tropical Water (TW) and the South Atlantic Central Water (SACW). The TW occurs in the first $200 \mathrm{~m}$ depth and it's a warm $\left(>18^{\circ} \mathrm{C}\right)$ and saline $(>36 \%)$ water mass. Below that, there is the SACW, characterized by lower temperatures $\left(6-20^{\circ} \mathrm{C}\right)$, lower salinity $(34.6-36 \%)$ and higher nutrient concentration. Therefore, the surface waters in the studied area are oligotrophic, and the SACW constitute the main source of nutrients due to the shoaling of the nutricline induced by the NE winds (intensified in summer) or by the upwelling in cyclonic eddies formed in the BC (Silveira et al., 2000).

\section{MATERIAL AND METHODS}

Piston core KF14 was retrieved from the Brazilian continental margin at $20^{\circ} 01^{\prime} 12^{\prime \prime} \mathrm{S} / 39^{\circ} 16^{\prime} 48^{\prime \prime} \mathrm{W}$, at $1671 \mathrm{~m}$ water depth (Figure 1), on the continental slope. It is located at the north of the Campos Basin. The 1621-cm-long sediment sequence mainly consists of continuous hemipelagic malm and mud, representing the last $440 \mathrm{kyr}$. However, there is an interruption of sedimentation between 93 and $285 \mathrm{~cm}$ depth, where a diamictite occurs, with unselected clasts. The age model is based on the correlation of the isotopic record of planktonicforaminifera with the LR04 isotopic curve of Lisiecki \& Raymo (2005), using the Analyseries 2.0 software (Paillard et al., 1996) (Figure 2). The correlation coefficient obtained between the curves (excluding the diamictite and previous samples of the KF14 core) was 0.71 .

Two radiocarbon datings, performed on 120 specimens of planktonic foraminifera Globigerinoides ruber $(>150 \mu \mathrm{m})$ each, were used as control points. Radiocarbon datings were performed at the National Facility Ocean Science Accelerator Mass Spectrometer Facility (NOSAMS) in the Woods Hole Oceanographic Institution, USA. The results were converted to calibrated ages using the calibration program of Stuiver \& Reimer (1993) (Table 1), using the Marine Reservoir Database (http://calib.qub.ac.uk/marine/) and marine09.14c (Reimer $e t$ al., 2009). A mean marine reservoir age of $350 \mathrm{yr}(\Delta \mathrm{R} 38 \pm$ $40 \mathrm{yr}$ ) was assumed.

The oxygen isotope stratigraphy of the core is based on the record of the planktonic foraminifera Globigerinoides ruber (white) $(>150 \mu \mathrm{m})$. Stable isotope measurements were 


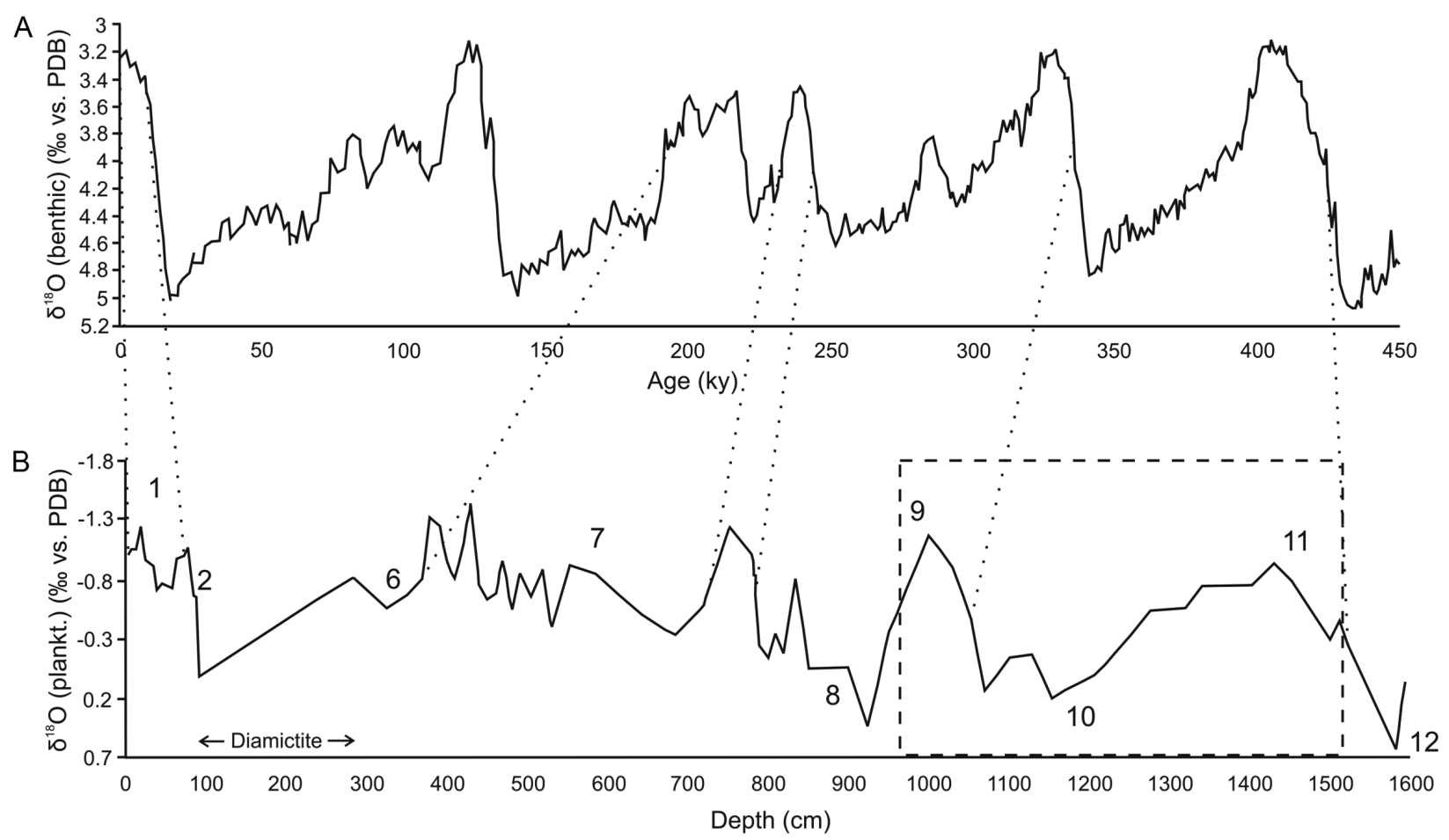

Figure 2. KF14 core model age from correlation with the standard curve LR04, indicating the Marine Isotope Stages (MIS). The interval corresponding to the diamictite comprises MIS 3,4 and 5.The dotted lines correspond to tie-points. The interval discussed in this work is highlighted (MIS 11-9).

Table 1. ${ }^{14} \mathrm{C}$ dating results and calibrated ages.

\begin{tabular}{cccc}
\hline Depth $(\mathrm{cm})$ & ${ }^{14} \mathrm{C}$ age & ${ }^{14} \mathrm{C}$ age corrected & Calibrated age \\
\hline 0 & $1250 \pm 20$ & 900 & 740 \\
75 & $6920 \pm 25$ & 6570 & 7415 \\
\hline
\end{tabular}

made at the Mass Spectometry Laboratory of University of California, USA, with Dual Inlet Isotope Ratioequipment (five specimens per sample).The tie-points used to correlate the LR0 4 curve to our data can be seen in the Table 2. The biostratigraphy based on planktonic foraminifera (Iwai, 2010) also backs up the age model. The presence of Globorotalia menardii in the samples is consistent with the $\mathrm{V}$ zone (Ericson \& Wollin, 1968) that comprehends MIS 11, 10, 9, 8 and 7.

Here, we present the results for the interval between 420 300 kyr. Micropaleontological and geochemical analyses were performed on the same samples, taken at intervals of 5 or $10 \mathrm{~cm}$. Slides for microscope analyses of coccolithophores were prepared according to Koch \& Young (2007). After oven drying the sediment, we removed a subsample of about 0.1 $0.2 \mathrm{~g}$, and diluted it in $10 \mathrm{ml}$ of buffered distilled water. The volume of suspension which contained $0.008 \mathrm{~g}$ of sediment was calculated, and a micropipette was used to transfer this volume to a second test-tube, with $10 \mathrm{ml}$ of buffered distilled water. $100 \mu \mathrm{l}$ of this second solution was pipetted onto a coverslip. After being quickly dried on a hot-plate, Canada balsam was used to mount slides. Since the weight of sediment transferred to the slide is known, counts of coccoliths per field of view can readily be converted into numbers of specimens per gram of sediment, as follows:

$$
\frac{\text { number of specimens }}{\text { gram of sediment }}=\frac{\mathrm{A} \times \mathrm{N}}{\mathrm{f} \times \mathrm{n} \times \mathrm{W}}
$$

where: $\mathbf{A}=$ coverslip area; $\mathbf{N}=$ number of specimens counted; $\mathbf{f}=$ area of one field of view; $\mathbf{n}=$ number of fields of view counted; $\mathbf{W}=$ weight of sediment on coverslip.

Observations were made using a light polarizing microscope $(1000 \times)$. At least 300 specimens were counted and identified, whereas Florisphaera profunda, ascidian spicules and Thoracosphaera sp. were considered separately. The taxonomic concepts of Young et al. (2003) and Jordan et al. (2004) were used.

The $N$ ratio (Flores et al., 2000) was calculated to assess the paleoproductivity. It is represented by the ratio of the absolute abundance of reticulofenestrids (Emiliania huxleyi and Gephyrocapsa spp. - opportunistic species) and reticulofenestrids and Florisphaera profunda (lower photic zone dweller). High values in the $N$ ratio imply a relatively shallow nutricline/thermocline position. Low values are interpreted as a relatively deep nutricline/thermocline position. 
Table 2. Tie points used to correlate the planktonic $\delta^{18} \mathrm{O}$ records of KF14 to the LR04 benthic $\delta^{18} \mathrm{O}$ stack.

\begin{tabular}{cc}
\hline KF14 depth $(\mathrm{cm})$ & Adopted age $(\mathrm{ka})$ \\
\hline 370 & 197.47 \\
725 & 234 \\
784 & 244.21 \\
1050 & 335 \\
1515 & 423 \\
\hline
\end{tabular}

The Shannon diversity index was calculated usig the free software PAST 2.05 (Hammer et al., 2001).The dissolution index (CEX) proposed by Baumann \& Freitag (2004) was used to verify the preferential dissolution of coccoliths.We included Reticulofenestra spp. instead of Emiliania huxleyi, which do not occur in this interval of time.

$$
\begin{gathered}
\text { CEX }=\frac{\% \text { Reticulofenestra } \text { ssp. }+\% \text { small Gephyrocapsa }}{\% \text { Reticulofenestra } \text { ssp. }+\% \text { small Gephyrocapsa }} \\
+\% \text { Calcidiscus leptoporus }
\end{gathered}
$$

\section{RESULTS}

In total, 34 coccolithophore taxa were identified, besides Thoracosphaera spp. and ascidian spicules.

The sedimentation rates during the interval we discuss in this paper were $5.2 \mathrm{~cm} / \mathrm{kyr}$ during MIS 11 and MIS 10 and $2.9 \mathrm{~cm} / \mathrm{kyr}$ during MIS 9.

The coccolith numbers were higher in early MIS 11, reaching $50.3 \times 10^{8}$ coccoliths $/ \mathrm{g}$; the lowest numbers were recorded in MIS 9. Shannon diversity varies from 0.69 to 1.7. The index was high in almost all the studied interval. $N$ ratio oscillated between 0.77 and 0.97 . There are no intervals of low $N$ ratio; disregarding isolated samples with lower values, the $N$ ratio is always higher than 0.85 . The coccolith dissolution index was high during the entire studied interval, pointing to a good preservation of the samples (Figure 3 ). In the studied interval, only four taxa are responsible by the behavior of the total coccolith numbers curve: Gephyrocapsa caribbeanica, small Gephyrocapsa, Reticulofenestra spp. and Florisphaera profunda. All the other taxa put together reached a maximum of $14.9 \%$, but usually much less (Figure 4 ).

The begging of MIS 11 is characterized by an abrupt increase in coccolith numbers at $420 \mathrm{ka}$, going from 28 to $50.3 \times 10^{8}$ coccoliths/g sediment. The $N$ ratio shows high values (Figure 3 ). During this interval of exceptionally high coccolith numbers, the assemblage is dominated by Gephyrocapsa caribbeanica, followed by small Gephyrocapsa (Figure 4). Around $410 \mathrm{ka}$, there is a severe decrease in coccolith numbers, accompanied by a fall in the $N$ ratio and a rise in the percentage of Florisphaera profunda, which reaches $15.8 \%$.
During the rest of MIS 11, $N$ ratio remains high (Figure 3). Small Gephyrocapsa and Gephyrocapsa caribbeanica dominate the assemblage, with an increase of the last one. Gephyrocapsa muellarae and Gephyrocapsa oceanica also stand out: G. muellarae is important between 419-391 kyr, while $G$. oceanica shows expressive percentage between 393-333 kyr (from the middle of MIS 11 to the beginning of MIS 9) (Figure 4).

During MIS 10, $N$ ratio remains high, but slightly decreases since 380 ka (Figure 3). Small Gephyrocapsa and Gephyrocapsa caribbeanica are the most abundant coccolithophorids, with dominance of small Gephyrocapsa since $328 \mathrm{ka}$ (Figure 4).

MIS 9 is characterized by the lowest coccolith numbers. The $N$ ratio is high but shows its lowest value at $328 \mathrm{ka}$. At the same time, the coccolith dissolution index shows a minimum peak and Shannon diversity index shows a maximum peak (Figure 3).The coccolith assemblage is dominated by small Gephyrocapsa and Florisphaera profunda. The percentage of Reticulofenestra spp. and the group of other species also peak at $328 \mathrm{ka}$. Gephyrocapsa oceanica and G. caribbeanica showed a decrease of percentage (Figure 4).

\section{DISCUSSION}

Observing the coccolith numbers or the $N$ ratio it is not possible to see a difference between MIS 11, 10 and 9. In general, the coccolith numbers was low, while the $N$ ratio was high. It may seem that during MIS 11 and 10 coccolith numbers was relatively high in comparison with samples below the peak between 420-410 kyr and of MIS 9. In fact, it was higher than the coccolith numbers found by Leonhardt et al. (2013) in the same area for the last $130 \mathrm{ka}$. However, the MBE is characterized by a rise in the carbonate accumulation. For this particular period, the KF14 coccolith numbers was much lower than the coccolith numbers found in southeast Atlantic (Baumann \& Freitag, 2004) or in the eastern equatorial Pacific (López-Otálvaro et al., 2008), for example. Therefore, it can be said that the KF14 coccolith numbers was low while the $N$ ratio was high through almost the entire studied interval.

This apparent incongruity can be explained by the adaptation of coccolithophorids to the oligotrophic waters. With the enhancement of nutrient availability, opportunistic species (Gephyrocapsa spp. and Reticulofenestra spp.) quickly respond, becoming more abundant than Florisphaera profunda (lower photic zone dweller). However, coccolithophorids cannot compete with phytoplankton groups that explore more efficiently this nutrient availability and have higher reproductive rates, such as diatoms (e.g. Broerse et al., 2000; Andruleit et al., 2003; Chen et al., 2007) and their absolute numbers remain low. Despite this, between 423-410 kyr, coccolith numbers and $N$ ratio were very high. For some reason, during this interval the other phytoplankton groups were not competitive (see discussion below).

The productivity was high throughout the studied interval, which can be explained, at least partially, by the MBE. 


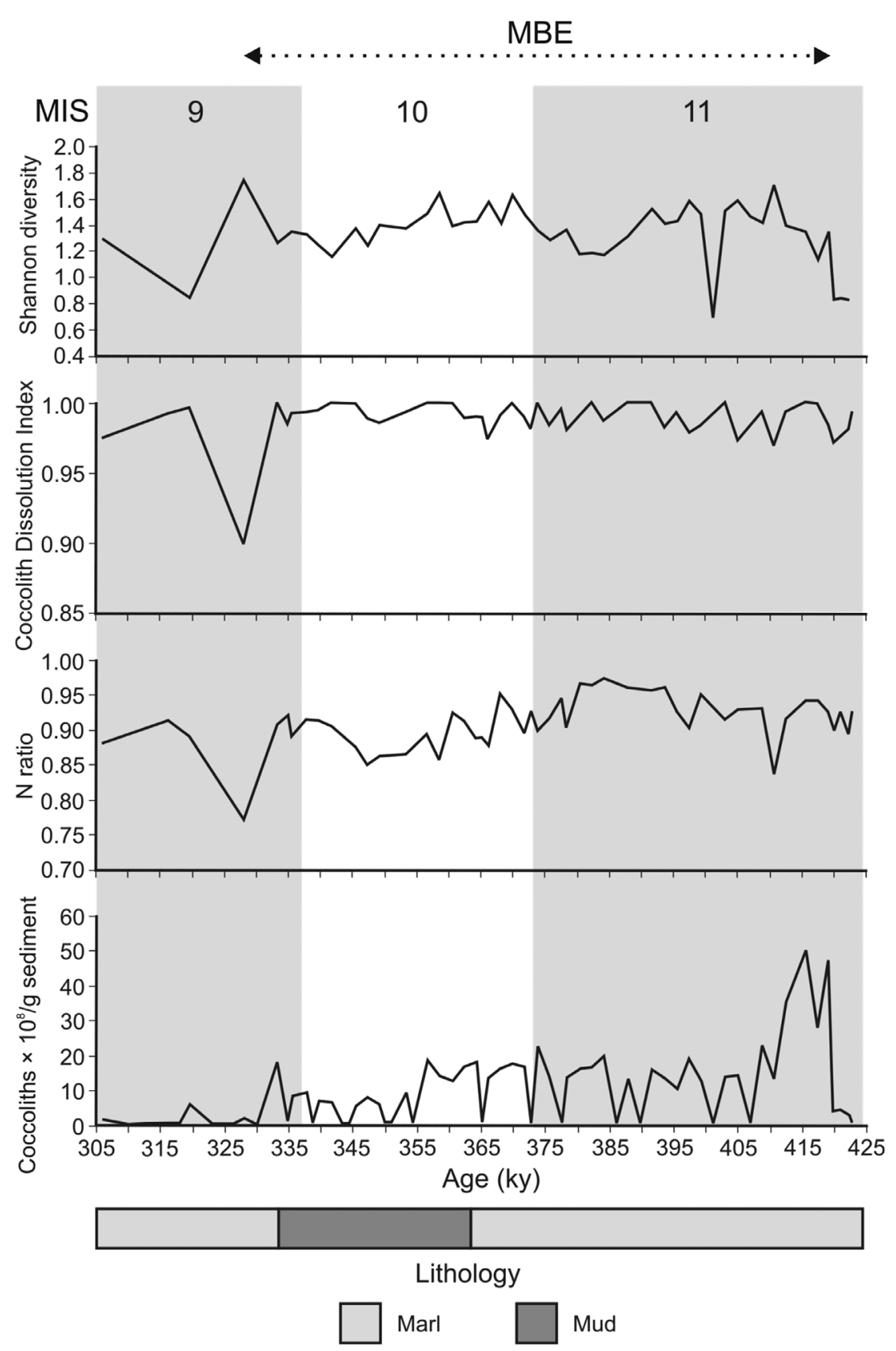

Figure 3.Total coccolith numbers, $N$ ratio, Coccolith Dissolution Index and Shannon diversity at KF14 core.

\section{Paleoceanographic changes during the MBE}

The interval from MIS 11 to 9 show high productivity, which is related to a shallower nutricline induced by the northeasterly winds of SASH or by upwelling development. Currently, the northeasterly winds become more intense when the SASH migrates to the southeast during the austral summer. However, the seasonal migration of SASH cannot be used as an analogous to their behavior in glacial and interglacial intervals: coccolithophore assemblages show no marked changes related to this cyclicity. This homogeneity of coccolithophore populations during glacial/interglacial intervals can be related to the MBE, when the atmospheric and oceanic circulations may have been intensified in the Southern Hemisphere, which could lead to a shallower nutricline and enhanced productivity in this interval.

The beginning of MIS 11 (between 420-410 kyr) stands out because it presents very high coccolith numbers, with high paleoproductivity (Figure 3). After $410 \mathrm{ka}$, the coccolith numbers decreased. According to the age model, there is no change in the sedimentation rate at this moment $(5.2 \mathrm{~cm} / \mathrm{kyr}$ during MIS 11 and 10), so this fluctuation in the coccolith numbers seems to be a real event. The high coccolith numbers, with high paleoproductivity, points to intense northeasterly winds or upwelling development and a different interaction between the phytoplankton groups. Diatoms and 

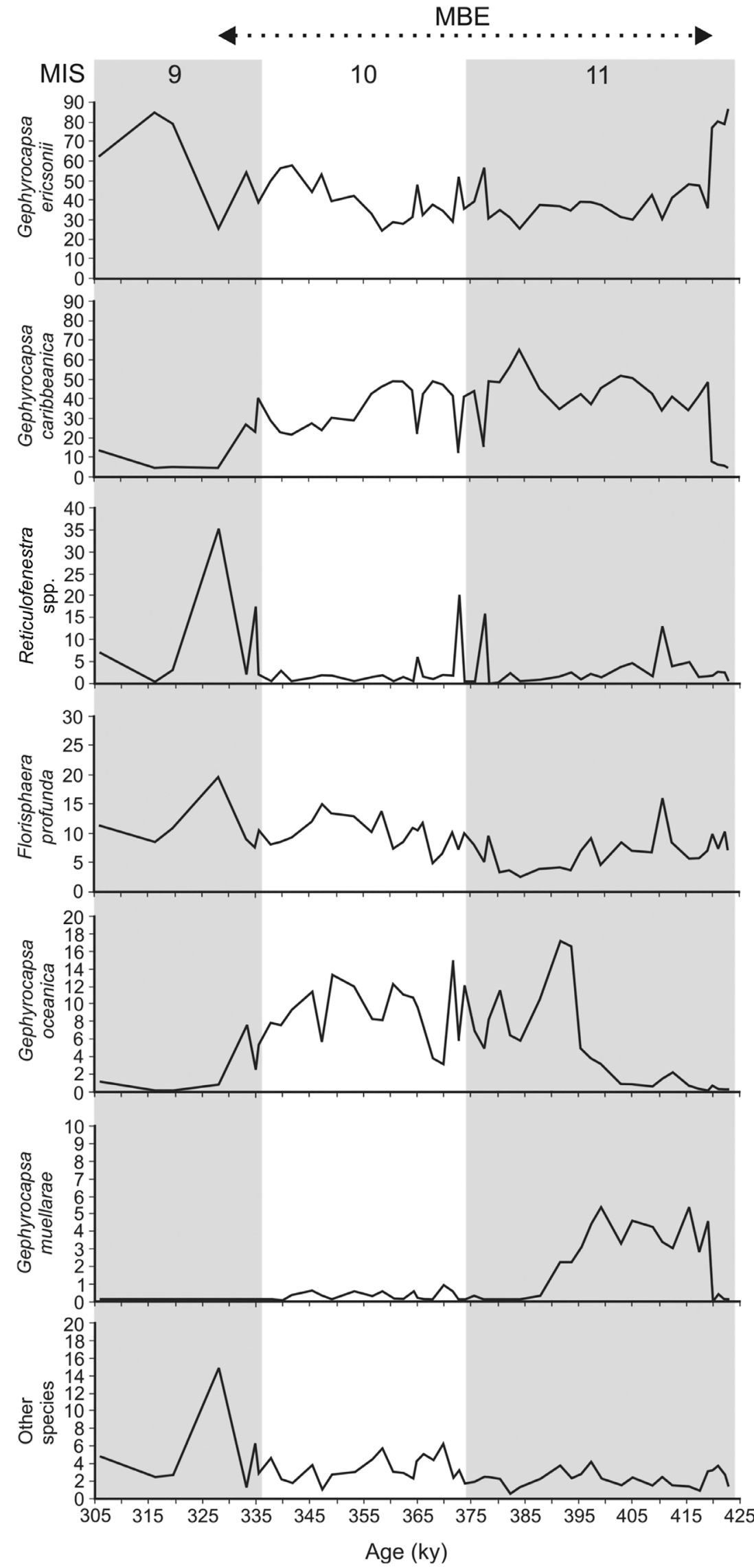

Figure 4. Relative abundances of selected species at KF14 core. 
coccolithophores compete for nutrients in the surface waters. Diatoms frequently dominate eutrophic environments. It is known that diatomaceous distribution is strongly regulated by the availability of dissolved silicates in seawater (e.g. Broerse et al., 2000). The high productivity recorded between 420-410 kyr in KF14 core, together with high coccolith numbers, may reflect the lack of silicate in the studied area. The possible lack of silicate in the studied area may be related to: (i) a decrease in the flow of the Doce River and the Paraiba do Sul River, the major rivers in the region; or (ii) a large marine transgression (the studied area would be far from the coast).

Other particularity of MIS 11 is the long duration of the deglaciation (430-410 kyr). The deglacial process stopped near $408 \mathrm{ka}$ (Bauch et al., 2000), and may have contributed to these changes in the properties of the seawater. Anyway, this unusual interval lasted $10 \mathrm{kyr}$. From $410 \mathrm{ka}$, the competition between the different phytoplankton groups seems to have returned to normal, with high productivity and smaller populations of coccolithophorids (Figure 3 ).

In two cores in a nearby area $\left(25^{\circ} \mathrm{S} / 43^{\circ} \mathrm{W}\right)$, Ferreira $e t$ al. (2014) found a short interval in the base of MIS 11 (420$390 \mathrm{ka})$ marked by higher carbonate contents. The authors also believe that this interval might reveal an increase in the primary productivity as suggested by planktonic and benthic foraminifera record. In their interpretation, this could be due to a development of an upwelling system. In our record, for the same interval, Gephyrocapsa muellarae shows high percentage (Figure 4). This species responds positively to elevated nutrient conditions and have affinity for cooler waters (Boeckel \& Baumann, 2004), giving support to the upwelling development possibility, although the interval of high coccolith numbers has ended before.

After $391 \mathrm{ka}$, Gephyrocapsa muellarae became inexpressive and $G$. oceanica shows high percentage until $328 \mathrm{ka}$ (beginning of MIS 9). This species also responds positively to elevated nutrient conditions, but has no preference for cooler waters (Boeckel \& Baumann, 2004). The paleoproductivity is still high, but there is no evidence of upwelling. This was also seen in the two cores investigated by Ferreira et al. (2014): according to them, the interval spanning from 390-290 ka (MIS 11-8) is marked by a decrease in the temperature and it interrupts or reduces upwelling.

During the MIS 10, a glacial stage, there is a weak decrease in paleoproductivity, indicating that the water became slightly more stratified. Ferreira et al. (2014) proposed a decrease of exportation of fresh organic matter (reduction of the upwelling system) as suggested by the benthic foraminifera record. In our record, productivity increases again at $341 \mathrm{ky}$ and remains high until MIS 9. However, around $328 \mathrm{ka}$, there is a peak of decreased productivity. At the same time, the diversity index reaches its maximum (Figure 3). Much of the coccolithophorid species does not respond to nutrient availability increase. The oligotrophic environment favors the increase of the group's diversity because opportunistic species are not benefited. These changes, together with the period of dominance of Gephyrocapsa caribbeanica (see next session), may mark the end of the influence of the MBE in the Southwestern Atlantic.

In the southeast Atlantic (in the same latitudinal range of this study), high coccolith numbers between MIS 14-9 were associated with a southward movement of the AngolaBenguela Front, which is indicative for weakened SE trade winds and a stronger influence of warm waters of the Angola Current (Baumann \& Freitag, 2004). This is in accordance with our data for MIS 11-9, with high productivity associated with intense northeasterly winds.

A period of high productivity related to the MBE is not restricted to the South Atlantic Ocean. In the eastern equatorial Pacific, MIS 14-8 are characterized by the higher paleoproductivity (Lopez-Otalvaro et al., 2008); this was also described by Álvarez et al. (2010) for the period between 450-220 kyr (MIS 12-7) in the tropical (Peru coast) and equatorial Pacific. The authors relate high productivity with a strengthening of the Southern Hemisphere circulation (stronger Trade Winds during the MBE) that allowed enhanced upwelling conditions, possibly related to dominant La Niña conditions (Lopez-Otalvaro et al., 2008; Álvarez et al., 2010). A similar chronology is found in the North Hemisphere: in the northwestern Pacific, the nutricline and termocline were shallow from 500 to $300 \mathrm{ka}$ (MIS 13-9), related to a weak monsoon in the East Asia (Chiyonobu et al., 2012). For the same region, Bordiga et al. (2014) also attribute to La Niña-like conditions (associated with the Kuroshio Current Extension in an elongated state) prevalent during the MBE the favorable conditions to coccolithophore proliferation and accumulation of their carbonate in sediments seem between MIS 12 to 8 . In the southern South China Sea, coccolithophorid data indicate that the paleoproductivity between MIS 13-8 was high and that the nutricline was shallow (Liu et al., 2008). In the Mediterranean Sea, coccolithophorid data suggest an enhanced primary productivity/mixed surface waters during interglacial stages and at Terminations between MIS 13-9 (Maiorano et al., 2013).

Other clues to understanding this period of high productivity came from the Southern Ocean. Geochemical (phosphorus) and micropaleontological proxies at millennial timescales reveal that the coccolithophore record in the Subantarctic zone of the South Atlantic Ocean is driven largely by the variations in marine phosphorus availability. The increase in productivity can be related to the northward displacement of the upwelling cell of the Antarctic divergence when the ice-sheet expanded and to the increase in the inventory of phosphorus in the ocean due to enhanced transfer of this nutrient from continental margins during glacial lowstands in sea level. The MBE is globally characterized by the dominance of Gephyrocapsa caribbeanica, which may be due to a shoaling of the thermocline, leading to an increase in productivity (Flores et al., 2012).

\section{The Gephyrocapsa caribbeanica rise and the MBDI}

During the MBE, the global development of Gephyrocapsa caribbeanica take place.The coccolithophore production was higher and indicates an increase in pelagic $\mathrm{CaCO}_{3}$ production. MIS 11 is marked by increased global carbonate dissolution and increased $\mathrm{CaCO}_{3}$ accumulation in many locations. Model 
experiments demonstrate that if the global dissolution during MBDI was caused by a reduced continental weathering, this would cause an increase in atmospheric $\mathrm{CO}_{2}$. On the other hand, by a combination of increased $\mathrm{CaCO}_{3} / \mathrm{C}_{\text {org }}$ production coupled with a strengthening of the organic pump (the ballast hypothesis suggests that $\mathrm{CaCO}_{3}$ may be the most important agent for transporting organic carbon from the ocean surface to the deep sea), the overall rate of $\mathrm{CaCO}_{3}$ dissolution can be increased while $\mathrm{CO}_{2}$ remains approximately constant. An increase in absolute coccolithophore production implies an increase in the production ratio $\mathrm{CaCO}_{3} / \mathrm{C}_{\text {org }}$ and is a good explanation for the MIS 11 paradox (Barker et al., 2006).

Furthermore, the coccolithophore production could be influenced by the orbital eccentricity through several mechanisms: interannual interplay between light intensity and length of growing season, length of winter, Si leakage from the Southern Ocean, high terrestrial productivity, etc (see Rickaby et al., 2007 for full discussion). These links, with little influence on atmospheric $\mathrm{CO}_{2}$, may explain the absence of a cycle in atmospheric $\mathrm{CO}_{2}$ coherent with the cycle in organic carbon burial.

Therefore, the abundance of Gephyrocapsa caribbeanica is of great importance for the understanding of these global climate changes. In core KF14, the period of dominance of G. caribbeanica was observed between 420-328 kyr (MIS 11-9). This is the first record of this event for the Southwestern Atlantic. Globally, this dominance can extend from MIS 14 to MIS 8.

Analysing cores covering equatorial to northern subpolar water masses, Bollmann et al. (1998) find that Gephyrocapsa caribbeanica dominate the assemblage of coccoliths during MIS 13-8. The earliest rise to dominance of Gephyrocapsa was observed at $633 \mathrm{ka}$ (MIS 16) in the Norwegian-Greenland Sea and the youngest was observed $150 \mathrm{kyr}$ later (MIS 13) in the western Pacific. The end of the dominance interval was synchronous at about $262 \mathrm{ka}$ (MIS 8). This period of dominance is recognized in many parts of the globe: in the eastern equatorial Pacific, during MIS 14-8 (Lopez-Otalvaro et al., 2008); in the southern South China Sea, from 480 to $250 \mathrm{ka}$ (MIS 13-8) (Liu et al., 2008); in the Mediterranean Sea, between MIS 13-8 ( $G$. caribbeanica and small Gephyrocapsa) (Incarbona et al., 2009; Maiorano et al., 2013); in the tropical (Peru coast) and equatorial Pacific, between 450-220 kyr (MIS 12-7) (Álvarez et al., 2010).

There are some evidences for the Atlantic Ocean too. In high latitudes, Hine \& Weaver (1998) and Villanueva et al. (2012) showed that the dominance interval of Gephyrocapsa caribbeanica ends during MIS 8. In the northeast Atlantic, $G$. caribbeanica dominates the assemblage from $546 \mathrm{ka}$ (MIS 14) until MIS 9 (when the record ends, and G. caribbeanica is still the dominant taxon). The highest percentages were recorded during MIS 13 (Amore et al., 2012). In the southeast Atlantic, the period of dominance were recorded between MIS 12-8 (Flores et al., 1999). The southeast Atlantic was also investigated by Baumann \& Freitag (2004) and, for the same latitudinal range of this study, the dominance of $G$. caribbeanica occurs from 560 to $280 \mathrm{kyr}$ (MIS 14-8). Further south, at Cape Basin (Southwest Africa), G. caribbeanica dominates the assemblage between MIS 11-8 (Flores et al., 2003). The G. caribbeanica record from core KF14 is different from what observed globally (the dominance ended earlier, during MIS 9) and suggest a peculiar local signal. The paleoceanographic significance of the period of global dominance of G. caribbeanica is still puzzling, making hard to explain this particularity.

As explained, this period of great proliferation of coccolithophorids leads to a high production of carbonate, but it is also marked by a great dissolution. Episodes of dissolution are described for various locationsand characterized the MBDI, occurring between MIS 14 to 9 with different chronologies. There are also several attempts to explain the phenomenon. The dissolution episodes in the western equatorial Atlantic ocurred when largest ice-shields were developed (Thiede et al., 1998). Such conditions would change the deep-water production, due to a southward shift of the North Atlantic Deep Water production area, leading to a greater admixture of corrosive Southern Component Deep Water (Gröger et al., 2003). In the Nordic Seas, the enhanced productivity could lead to high rates in vertical flux of fresh total organic carbon. This could have changed bottom water $\mathrm{CO}_{2}$ via remineralization and, thus, calcite solubility above the lysocline (Bauch et al., 2000). For many locations in the Atlantic ocean (southeast Atlantic - Baumann \& Freitag, 2004; southwest Africa Flores et al., 2003; northeast Atlantic - Amore et al., 2012) the intervals of dissolution are coincident with high abundances of Gephyrocapsa caribbeanica, which is a highly calcified species. This could confirm the hypothesis of an influence of this species proliferation in altering marine carbonate chemistry, because its intensive calcification caused a carbonate-ion under saturation. These different explanations are not mutually exclusive and one may have greater importance in a particular location.

However, in core KF14 there is no evidence of dissolution during the MBE. There was only one peak in the Coccolith Dissolution Index at $328 \mathrm{ka}$ (Figure 3), but still characterizing a well-preserved sample. Although an interval of dissolution during the MBE is globally recognized, other studies indicate sites in which it did not occured. For example, good to moderate coccolithophore preservation is found in the eastern equatorial Pacific. MIS 14-8 are characterized by the highest carbonate content, essentially produced by Gephyrocapsa caribbeanica. This suggests that there was no vertical change in the water masses overlying the sediment, and hence the carbonate compensation depth and the lysocline must have been deeper than $2900 \mathrm{~m}$ during that event. This could be the consequence of high local rates of carbonate supply to deep waters in this location (Lopez-Otalvaro et al., 2008). In addition, severe carbonate dissolution did not occur above the lysocline in the western equatorial Pacific, but only below the lysocline (Zhang et al., 2007). Their data indicate that primary productivity is not an important causal factor for formation of carbonate cycles (accumulation and dissolution).

Our data indicate that the lysocline should have remained deeper than $1671 \mathrm{~m}$ water depth in the Southwestern Atlantic Ocean and that the North Atlantic Deep Water (water mass overlying the sediments at the depth in which KF14 core was 
collected) preserved its physico-chemical characteristics even during the MBDI.

The absence of dissolution may be linked to the relatively low coccolith numbers found in KF14 core when compared with other areas. The global enhancement in pelagic carbonate production (due to the increase of Gephyrocapsa caribbeanica populations) exaggerates the disequilibrium between produced $\mathrm{CaCO}_{3}$ and buried $\mathrm{CaCO}_{3}$. Therefore, dissolution is forced because the waters became carbonate-ion under saturated or because the export of organic carbon to the deep ocean increased. The increase in G. caribbeanica populations registered in KF14 core has not the same magnitude and ended earlier than in other sites. Hence, in this area, carbonate dissolution was not induced.

\section{CONCLUSIONS}

The coccolithophores assemblages between 423-305 kyr (MIS 11-9) allowed a paleoceanographic reconstruction in the Southwest Atlantic in a time interval poorly studied in the region. The key findings generated by this study are: (i) the paleoproductivity remains high throughout the analyzed interval; (ii) between 420-410 kyr, coccolithophorids had large populations at a time of high productivity, which may indicate lack of silicates in the surface waters of the study area; (iii) the period of dominance of Gephyrocapsa caribbeanica was recognized between 420-328 kyr and it is related to the MBE, reinforcing the occurrence of this event in the Southwestern Atlantic Ocean; (iv) there was no significant dissolution of carbonates during the Mid-Brunhes at the southeastern Brazilian continental margin.

\section{ACKNOWLEDGMENTS}

The authors are indebted to CNPq (Brazilian National Council for Scientific and Technological Development) for the financial support (processes 471611/2010-7 and 304453/2013-7). They also thank the Petróleo Brasileiro S.A. (PETROBRAS) by the samples. A.L. is grateful to CNPq for having granted a scholarship and to CAPES (Brazilian Coordination of Higher Education Staff Improvement) for the financial support that enabled the presentation of this work at the XI International Conference of Paleoceanography (process number 6365-13-2). The authors are also thankfull to the referees ad hoc and to M. Pivel and M. Ritter for the improvement of the original manuscript.

\section{REFERENCES}

Álvarez, M.C.; Flores, J.A.; Sierro, F.J \& Molina-Cruz, A. 2010. Longterm upwelling evolution in tropical and equatorial Pacific during the last $800 \mathrm{kyr}$ as revealed by coccolithophore assemblages. Geobios, 43:123-130. doi: 10.1016/j.geobios.2009.07.001

Amore, F.O.; Flores, J.A.; Voelker, A.H.L.; Lebreiro, S.M.; Palumbro, E. \& Sierro, F.J. 2012. A Middle Pleistocene Northeast Atlantic coccolithophore record: paleoclimatology and paleoproductivity aspects. Marine Micropaleontology, 90-91:44-59. doi: 10.1016/j. marmicro.2012.03.006
Andruleit, H.; Stager, S.; Rogalla, U. \& Cepek, P. 2003. Living coccolithophores in the northern Arabian Sea: ecological tolerances and environmental control. Marine Micropaleontology, 49:157-181. doi: 10.1016/S0377-8398(03)00049-5

Barker, S.; Archer, D.; Boothe, L.; Elderfield, H.; Henderiks, J. \& Rickaby, R.E.M. 2006. Globally increased pelagic carbonate production during the Mid-Brunhes dissolution interval and the $\mathrm{CO}_{2}$ paradox of MIS 11. Quaternary Science Reviews, 25:32783293. doi: 10.1016/quascirev.2006.07.018

Bauch, H.A.; Erlenkeuser, H.; Helmke, J. P. \& Struck, U. 2000. A paleoclimatic evaluation of marine oxygen isotope stage 11 in the high-northern Atlantic (Nordic seas). Global and Planetary Change, 24:27-39. doi: 10.1016/S0921-8181(99)00067-3

Baumann, K.H. \& Freitag, T. 2004. Pleistocene fluctuations in the northern Benguela current system as revealed by coccolith assemblages. Marine Micropaleontology, 52:195-215. doi: 10.1016/j.marmicro.2004.04.011

Boeckel, B. \& Baumann, K.H. 2004. Distribution of coccoliths in surface sediments in the south-eastern South Atlantic Ocean: ecology, preservation and carbonate contribution. Marine Micropaleontology, 51:301-320. doi: 10.1016/j. marmicro.2004.01.001

Bollmann, J.; Baumann, K.-H. \& Thierstein, H.R. 1998. Global dominance of Gephyrocapsa coccoliths in the late Pleistocene: selective dissolution, evolution, or global environmental change? Paleoceanography, 13:517-529. doi 10.1029/98PA00610

Bordiga, M.; Cobianchi, M.; Lupi, C.; Pelosi, N.; Venti, N.V. \& Ziveri, P. 2014. Coccolithophore carbonate during the last 450 ka in the NW Pacific Ocean (ODP site 1209B, Shatsky Rise). Journal of Quaternary Science, 29:57-69. doi: 10.1002/jqs.2677

Broerse, A.T.C.; Ziveri, P.; Hinte, J.E. \& Honjo, S. 2000. Coccolithophore export production, species composition, and coccolith $\mathrm{CaCO}_{3}$ fluxes in the NEAtlantic $\left(34^{\circ} \mathrm{N} 21^{\circ} \mathrm{W}\right.$ and $\left.48^{\circ} \mathrm{N} 21^{\circ} \mathrm{W}\right)$. Deep-Sea Research II, 47:1877-1905. doi: 10.1016/S0967-0645(00)00010-2

Candy, I.; Coope, G.R.; Lee, J.R.; Parfitt, S.A.; Preece, R.C.; Rose, J. \& Schreve, D.C. 2010. Pronounced warmth during early Middle Pleistocene interglacials: investigating the Mid-Brunhes Event in the British terrestrial sequence. Earth-Science Reviews, 103:183-196. doi: 10.1016/j.earscirev.2010.09.007

Candy, I. \& McClymont, E.L. 2013. Interglacial intensity in the North Atlantic over the last 800,000 years: investigating the complexity of the mid-Brunhes Event. Journal of Quaternary Science, 28:343-348. doi: 10.1002/jqs.2632

Chen, Y.L.; Chen, H.Y. \& Chung, C.W. 2007. Seasonal variability of coccolithophore abundance and assemblage in the northern South China Sea. Deep-Sea Research II, 54:1617-1633. doi: 10.1016/j.dsr2.2007.05.005

Chiyonobu, S.; Mori, Y. \& Oda, M. 2012. Reconstruction of paleoceanographic conditions in the northwestern Pacific Ocean over the last $500 \mathrm{kyr}$ based on calcareous nannofossil and planktic foraminiferal assemblages. Marine Micropaleontology, 96-97:29-37. doi: 10.1016/j.marmicro.2012.07.002

EPICA Community Members, 2004. Eight glacial cycles from an Antarctic ice core. Nature, 429:623-628. doi: 10.1038/ nature02599

Ericson, D.B. \& Wollin, G. 1968. Pleistocene climates and chronology in deep-sea sediments. Science, 162:1277-1234. doi: 10.1126/science.162.3859.1227

Ferreira, F.; Frontalini, F.; Leão, C.J. \& Leipnitz, I.I. 2014. Changes in the water column structure and paleoproductivity in the western South Atlantic Ocean since the middle Pleistocene: evidence from benthic and planktonic foraminifera. Quaternary International, 352:111-123. doi: 10.1016/j.quaint.2014.07.061 
Flores, J.A.; Barcena, M.A. \& Sierro, F.J. 2000. Ocean-surface and wind dynamics in the Atlantic Ocean off Northwest Africa during the last 140,000 years. Palaeogeography, Palaeoclimatology, Palaeoecology, 161:459-478. doi: 10.1016/ S0031-0182(00)00099-7

Flores, J.A.; Filipelli, G.M.; Sierro, F.J. \& Latimer, J. 2012. The "White Ocean" hypothesis: a late Pleistocene Southern Ocean governed by coccolithophore and driven by phosphorus. Frontiers in Microbiology, 3:1-13. doi: 10.3389/fmicb.2012.00233

Flores, J.A.; Gersonde, R. \& Sierro, F.J. 1999. Pleistocene fluctuations in the Agulhas Current retroflection based on the calcareous plankton record. Marine Micropaleontology, 37:1-22. doi: 10.1016/S0377-8398(99)00012-2

Flores, J.A.; Marino, M.; Sierro, F.J.; Hodell, D.A. \& Charles, C.D. 2003. Calcareous plankton dissolution pattern and coccolithophore assemblages during the last $600 \mathrm{kyr}$ at ODP site 1089 (Cape Basin, South Atlantic): paleoceanographic implications. Palaeogeography, Palaeoclimatology, Palaeoecology, 196:409426. doi: 10.1016/S0031-0182(03)00467-X

Gröger, M.; Henrich, R. \& Bickert, T. 2003. Glacial-interglacial variability in lower North Atlantic deep water: inference from silt grain-size analysis and carbonate preservation in the western equatorial Atlantic. Marine Geology, 201:321-332. doi: 10.1016/ S0025-3227(03)00263-9

Hammer, Ø.; Harper, D.A.T. \& Ryan, P.D. 2001. PAST: Paleontological statistics software package for education and data analysis. Palaeontologia Electronica, 4. Available at http:// palaeo-lectronica.org/2001_1/past/issue1_01.htm; accessed on $22 / 08 / 2012$.

Hastenrath, S. 1991. Climate dynamics of the tropics. $2^{\text {nd }}$ ed. New York, Kluwer Academic Publishers, 488 p.

Hay, W.W. 1977. Calcareous nannofossils. In: A.T.S. Ramsay (ed.) Oceanic Micropaleontology, Academic Press, p. 1055-1200.

Hine, N. \& Weaver, P.P.E. 1998. Quaternary. In: P.R. Bown (ed.) Calcareous nannofossil biostratigraphy, Kluwer Academic Publishers, p. 266-283.

Incarbona, A.; Di Stefano, E. \& Bonomo, S. 2009. Calcareous nannofossil biostratigraphy of the Central Mediterranean Basin during the last 430,000 years. Stratigraphy, 6:33-44.

Iwai, F.S. 2010. Assembleias de foraminíferos planctônicos: implicações paleoceanográficas nos últimos 450.000 anos em testemunhos do sudoeste do Atlântico Sul. Programa de PósGraduação em Oceanografia Química e Geológica, Universidade de São Paulo, M.Sc. thesis, 135 p.

Jansen, J.H.F.; Kuijpers, A. \& Troelstra, S.R. 1986. A Mid-Brunhes climatic event: long-term changes in global atmosphere and ocean circulation. Science, 232:619-622. doi: 10.1126/ science.232.4750.619

Jordan, R.W.; Cros, L. \& Young, J.R. 2004. A revised classification scheme for living haptophytes. Micropaleontology, 50:55-79. doi: 10.2113/50.Suppl_1.55

Koch, C. \& Young, J.R. 2007. A simple weighing and dilution technique for determining absolute abundance of coccoliths from sediment samples. Journal of Nannoplankton Research, 29:67-69.

Lass, H.U. \& Mohrholz, V. 2008. On the interaction between the subtropical gyre and the subtropical cell on the shelf of the SE Atlantic. Journal of Marine Systems, 74:1-43. doi: 10.1016/j. jmarsys.2007.09.008

Leonhardt, A.; Toledo, F.A.L. \& Coimbra, J.C. 2013. The productivity history in the Southwestern Atlantic as inferred from coccolithophore record for the last $130 \mathrm{kyr}$. Revista Brasileira de Paleontologia, 16:361-374. doi: 10.4072/rbp.2013.3.02
Lisiecki, L.E. \& Raymo, M.E. 2005. A Pliocene-Pleistocene stack of 57 globally distributed benthic $\delta^{18} \mathrm{O}$ records. Paleoceanography, 20:1-17. doi: 10.1029/2004PA001071

Liu, C.; Wang, P.; Tian, J. \& Cheng, X. 2008. Coccolith evidence for Quaternary nutricline variations in the southern South China Sea. Marine Micropaleontology, 69:42-51. doi: 10.1016/j. marmicro.2007.11.008

Lopez-Otalvaro, G.E.; Flores, J.A.; Sierro, F.J. \& Cacho, I. 2008. Variations in coccolithophorid production in the Eastern Equatorial Pacific at ODP site 1240 over the last seven glacialinterglacial cycles. Marine Micropaleontology, 69:52-69. doi: 10.1016/j.marmicro.2007.11.009

Loutre, M.F. \& Berger, A. 2000. Future climatic changes: are we entering an exceptionally long interglacial? Climate change, 46:61-90. doi: 10.1023/A:1005559827189

Loutre, M.F. \& Berger, A. 2003. Marine Isotope Stage 11 as an analogue for the present interglacial. Global and Planetary Change, 36:209-217. doi: 10.1016/S0921-8181(02)00186-8

Maiorano, P.; Tarantino, F.; Marino, M. \& Lange, G.J. 2013. Paleoenvironmental conditions at core $\mathrm{KC01B}$ (Ionian Sea) through MIS 13-9: evidence from calcareous nannofossil assemblages. Quaternary International, 288:97-111. doi: 10.1016/jquaint.2011.12.007

Paillard, D.; Labeyrie, L. \& Yiou, P. 1996. Macintosh program performs time-series analysis. Eos, 77:379. doi: 10.1029/96EO00259

Perch-Nielsen, K. 1985. Cenozoic calcareous nannofossils. In: H.M. Bolli; J.B. Saunders \& K. Perch-Nielsen (eds.) Plankton stratigraphy, Cambridge University Press, p. 427-554.

Peterson, R.G. \& Stramma, L. 1991. Upper-level circulation in the South Atlantic Ocean. Progress in Oceanography, 26:1-73. doi: 10.1016/0079-6611(91)90006-8

Rickaby, R.E.M.; Bard, E.; Sonzogni, C.; Rostek, F.; Beaufort, L.; Barker, S.; Rees, G. \& Schrag, D.P. 2007. Coccolith chemistry reveals secular variations in the global ocean carbon cycle? Earth and Planetary Science Letters, 253:83-95. doi: 10.1016/j. epsl.2006.10.016

Rodrigues, R.R.; Rothstein, L.M. \& Wimbush, M. 2007. Seasonal variability of the South Equatorial Current bifurcation in the Atlantic Ocean: a numerical study. Journal of Physical Oceanography, 37:16-30. doi: 10.1175/JPO2983.1

Reimer, P.J. et al. 2009. IntCal09 and Marine09 radiocarbon age calibration curves, 0-50,000 years cal. BP. Radiocarbon, 51:1111-1150. doi: 10.2458/azu_js_rc.51.3569

Silveira, I.C.A.; Schmidt, A.C.K.; Campos, E.J.D.; Godoi, S.S. \& Ikeda, Y. 2000. A Corrente do Brasil ao largo da costa leste brasileira. Revista Brasileira de Oceanografia, 48:171-183. doi: 10.1590/S1413-77392000000200008

Stuiver, M. \& Reimer, P.J. 1993. Extended ${ }^{14} \mathrm{C}$ data base and revised Calib $3.0{ }^{14} \mathrm{C}$ age calibration program. Radiocarbon, 35:215-230.

Thiede, J.; Winkler, A.; Wolf-Welling, T.; Eldholm, O.; Myhre, A.M.; Baumann, K.-H.; Henrich, R. \& Stein, R. 1998. Late Cenozoic history of the polar North Atlantic: results from ocean drilling. Quaternary Science Reviews, 17:185-208. doi: 10.1016/S02773791(97)00076-0

Tzedakis, P.C.; Channel, J.E.T.; Hodell, D.A.; Kleiven, H.F. \& Skinner, L.C. 2012. Determining the natural lenght of the current interglacial. Nature Geosciences, 5:138-141. doi: 10.1038/ngeo1358

Villanueva, J.; Flores, J.A. \& Grimalt, J.O. 2002. A detailed comparison of the $\mathrm{U}^{\mathrm{K}}{ }_{37}$ and coccoltih records over the past 290 kyears: implications to the alkenone paleotemperature method. Organic Geochemistry, 33:897-905. doi: 10.1016/ S0146-6380(02)00067-0 
Wang, P.; Li, Q.; Tian, J.; Jian, Z.; Liu, C.; Li, L. \& Ma,W. 2014 Long-term cycles in the carbon reservoir of the Quaternary ocean: a perspective from the South China Sea. National Science Review, 1:119-143. doi: 10.1093/nsr/nwt028

Yin, Q.Z. \& Berger, A. 2010. Insolation and $\mathrm{CO}_{2}$ contribution to the interglacial climate before and after the Mid-Brunhes event. Nature Geoscience, 3:243-246. doi: 10.1038/NGEO0771

Yin, Q. 2013. Insolation-induced mid-Brunhes transition in southern ocean ventilations and deep-ocean temperature. Nature, 494:222225. doi: 10.1038/nature 11790
Young, J.R.; Geisen, M.; Cros, L.; Kleijne, A.; Sprengel, C.; Probert, I. \& Østergaard, J.B. 2003. A guide to extant coccolithophore taxonomy. Journal of Nannoplankton Research, 1:1-121.

Zhang, J.; Wang, P.; Li, Q.; Cheng, X.; Jin, H. \& Zhang, S. 2007. Western equatorial Pacific productivity and carbonate dissolution over the last $550 \mathrm{kyr}$ : foraminiferal and nannofossil evidence from ODP Hole 807A. Marine Micropaleontology, 64:121-140. doi: 10.1016/j.marmicro.2007.03.003

Received in June, 2015; accepted in November, 2015. 